\title{
Preterm birth, intrauterine infection, and fetal inflammation
}

\author{
Matthew W. Kemp* \\ School of Women's and Infants' Health, The University of Western Australia, Perth, WA, Australia
}

\section{Edited by:}

Claudia Monaco, Catholic University Rome \& Imperial College, UK

\section{Reviewed by:}

Marian Kacerovsky, University Hospital in Prague, Czech Republic Ana María Franchi, The National Scientific and Technical Research Council (CONICET), Argentina

*Correspondence:

Matthew W. Kemp, School of Women's and Infants' Health, The University of Western Australia, M550, 35 Stirling Highway, Crawley, Perth WA 6009, Australia e-mail:matthew.kemp@uwa.edu.au
Preterm birth (PTB) (delivery before 37 weeks' gestation) is a leading cause of neonatal death and disease in industrialized and developing countries alike. Infection (most notably in high-risk deliveries occurring before 28 weeks' gestation) is hypothesized to initiate an intrauterine inflammatory response that plays a key role in the premature initiation of labor as well as a host of the pathologies associated with prematurity. As such, a better understanding of intrauterine inflammation in pregnancy is critical to our understanding of preterm labor and fetal injury, as well as on-going efforts to prevent PTB. Focusing on the fetal innate immune system responses to intrauterine infection, the present paper will review clinical and experimental studies to discuss the capacity for a fetal contribution to the intrauterine inflammation associated with PTB. Evidence from experimental studies to suggest that the fetus has the capacity to elicit a pro-inflammatory response to intrauterine infection is highlighted, with reference to the contribution of the lung, skin, and gastrointestinal tract. The paper will conclude that pathological intrauterine inflammation is a complex process that is modified by multiple factors including time, type of agonist, host genetics, and tissue.

Keywords: preterm birth, fetus, inflammation, infection, injury

\section{INTRODUCTION}

Preterm birth (PTB) is presently defined as delivery before 37 weeks' completed gestation from the last known menstrual period (1); the lower limit of PTB varies between countries but is generally set at 20 or 22 weeks' completed gestation (2). PTB is often further sub-classified into late (32 or 34-36 completed weeks' gestation), early ( $<32$ completed weeks' gestation), and very early ( $<28$ completed weeks' gestation) delivery $(2,3)$. These definitions are now viewed as somewhat arbitrary in nature and susceptible to classification bias because of the methodologies used to assess gestational age (self-reported last menstrual period vs. ultrasound measurement $)(2,4,5)$. These measures also fail to account for a host of pregnancy characteristics (e.g., infection, maternal health status, and fetal distress) that are likely key to both the treatment of the preterm infant and our attempts to better understand and prevent PTB. As such, a number of investigators have recommended the adoption of an information-rich, phenotypic PTB classification system that considers births occurring after 16 and before 39 weeks of completed gestation (5).

Preterm birth is a significant global health issue. Rates of PTB vary with ethnicity, geography, and a range of lifestyle factors (6); in 2003, the rate of PTB for Asian, Caucasian, and African American women in the United States was 10.5, 11.5, and 17.8\%, respectively (7). Complications of prematurity account for $29 \%$ of global neonatal deaths (approximately 1 million) each year and $3.1 \%$ of total disability adjusted life years in the global burden of disease $(8,9)$. Underscoring the scope of the PTB problem, recent data suggest that just a 5\% relative reduction (from 9.59 to $9.07 \%$ ) in the rate of PTB across 39 countries with a very highhuman development index would yield some 58,000 fewer preterm deliveries and a saving of US $\$ 3$ billion (10).
From a pathophysiological perspective, PTB is a highly complex and incompletely understood syndrome $(11,12)$. Evidence exists to implicate a host of factors including uteroplacental ischemia, cervical disease, decidual hemorrhage, stress, infection, and inflammation in the initiation of prematurity (12). Inflammation (with or without hypoxia) is also strongly implicated in a host of fetal morbidities. It is hypothesized that these, and perhaps other factors, acting either independently or in concert, trigger a suite of changes in gestational tissues that shift the uterus from a state of quiescence to one of activity in the initiation of labor. Gotsch and colleagues have described the tripartite uterine components of a (p. 6) "common pathway of parturition" as including an increase in myometrial contractility coupled with ripening of the cervix and activation of the fetal membranes and decidua $(3,12)$.

The immune system is hypothesized to play a key role in regulating the above processes, and a compelling body of evidence exists to suggest that both term and preterm labor are characterized by significant pro-inflammatory changes in gestational tissues (12-14). One point of difference is that the inflammation identified in term labor is commonly thought to be lower in magnitude than that identified in PTB $(3,12)$. Labor-associated inflammatory changes are characterized by immunocyte infiltration and significant increases in the expression of interleukin (IL)- $1 \beta$, IL6, IL-8, monocyte chemoattractant protein (MCP)-1, and tumor necrosis factor (TNF)- $\alpha$ expression in the fetal membranes, cervix, amniotic fluid, and placenta. Expression of pro-inflammatory mediators is, in turn, hypothesized to result in (i) increases in prostaglandins, which promote uterine contractility; (ii) degradation of the chorioamnion extracellular matrix; and (iii) ripening of the cervix by matrix metalloproteinases and reduced expression of tissue metalloproteinase inhibitors (14). 
A complex regulatory network involving Th1 (IL-12 polarized CD $4^{+}$T-cells characterized by interferon- $\gamma$ expression), Th2 (IL-4 polarized CD4 ${ }^{+}$T-cells characterized by IL-4, IL-10, and IL-13 expression), Treg (CD4 ${ }^{+} \mathrm{CD} 25^{+}$T-cells expressing the transcription factor FOXP3), Th17 (CD4 ${ }^{+}$T-cells that secrete IL-17a and IL-17f), and uterine natural killer cells is hypothesized to be of critical importance in the establishment and prolongation of pregnancy (13-15). This network, in turn, is susceptible to regulation by the pro- and anti-inflammatory actions of a host of endocrine factors including progesterone, estrogen, human chorionic gonadotrophin, and luteinizing hormone $(14,15)$.

There is also good evidence to suggest that pro-inflammatory signaling following activation of the innate immune system, in response to injury or infection, plays an important role in the premature initiation of labor (11). Infection is most commonly identified in the earliest of preterm deliveries, those occurring before 28 weeks of gestational age. Goldenberg et al. suggest that the $25-40 \%$ of preterm deliveries ascribed to intrauterine infection may be a minimum estimate due to potential culture and sample selection bias (11). Similarly, histologic chorioamnionitis, a hallmark of intrauterine infection, has been reported in nearly $70 \%$ of preterm deliveries between 20 and 24 weeks' gestational age, but in only $16 \%$ of cases delivered at 34 weeks (16). Recent data indicate that intrauterine infection is frequently polymicrobial in nature. Although bacterial nucleic acids have been identified in chorioamnion from both term and very preterm deliveries, samples from very preterm deliveries have been found to contain the largest diversity and distribution of bacterial species (17). The microorganisms most commonly identified in cases of PTB include the Ureaplasma spp. (in particular, Ureaplasma parvum), Mycoplasma hominis, and the Fusobacterium spp. There is also increasing evidence for the importance of Candida spp. in intraamniotic infection (18-20) and much remains to be understood in relation to the potential for viral infection to play a role in the pathological processes that underpin PTB.

We have previously speculated that the development of efficacious therapies for infection-associated PTB is likely predicated on our ability to resolve both intrauterine infection and the concomitant intrauterine inflammation that results (21). However, we also suggest that any attempts to regulate intrauterine inflammation must be undertaken with caution; regulated expression of cytokines plays an important role in the development of a number of fetal organs, including the skin, lung, and brain. To this end, identifying the origins and nature of the pathological inflammation that accompanies intrauterine infection is an important step in our efforts to deliver targeting anti-inflammatory therapies.

There is a wealth of data available to describe the proinflammatory responses of placental, uterine, cervical, and chorioamnion tissues to intrauterine infection. The contributions of somatic fetal tissues to both intrauterine inflammation and the fetal inflammatory response syndrome (FIRS; defined on the basis of a cord blood plasma IL- 6 concentration $>11 \mathrm{pg} / \mathrm{mL}$ ) associated with intrauterine infection are, in contrast, much less well characterized.

The remainder of this paper will focus on data provided by basic science and clinical studies to (i) describe the capacity of fetal tissues, in particular, the skin, lung, gastrointestinal tract to mount a pro-inflammatory reaction in response to stimulation of the innate immune system by microbial agonist; and (ii) comment on some of the evidence, to date, that suggests an important role for these fetal tissues in driving the intrauterine inflammatory response implicated in PTB and fetal injury.

\section{CAPACITY OF FETAL TISSUES TO MOUNT A RESPONSE TO INFECTION AND INJURY VIA THE INNATE IMMUNE SYSTEM}

The innate immune system is a critical element of host defense against microbial invasion. Broadly speaking, the innate immune system comprises humoral (endogenous antibodies and complement) and cellular (recognition of conserved pathogen motifs by natural killer cells, monocytes, macrophages, and non-immune cells including endothelial cells and neuronal cells, stimulating phagocytosis and or the release of pro-inflammatory cytokines, chemokines, and defensins) elements (22). Together, these act in concert to recognize and resolve infection in addition to serving as a means of coupling innate immune responses to the induction and amplification of a subsequent adaptive immune system response. A detailed treatment of the innate immune system is beyond the scope of this work and a number of excellent review articles have recently dealt with elements of the innate immune system including complement (23), toll-like receptors (TLRs) (24), Nod-like receptors (25), and defensins (26). Rather, this work will take three key elements of the innate immune system, namely, pattern-recognition receptors, complement, and defensins, and explore the evidence for their expression in developing fetal tissues.

\section{PATTERN-RECOGNITION RECEPTORS}

Pattern-recognition receptors (PRRs) are innate immune system receptors that recognize structurally stable microbial elements (27). In addition, PRRs can recognize molecules that are released in response to tissue injury or stress $(24,27)$. Their immunological role is considered to be of great importance as their conserved ability to recognize pathogens and/or injury allows for an initial defensive reaction, which simultaneously recruits elements of the adaptive immune system to respond to a potential infectious threat. PRR ligand binding results in the activation of multiple signaling factors (including NF- $\kappa \mathrm{B}$ and interferon-regulatory factors), yielding cytokine and chemokine expression, with downstream effects including enhanced phagocytosis, pyrexia, increased rates of hematopoiesis, elevated type-I interferon expression, and pyroptosis (27).

Toll-like receptors are a large family of transmembrane proteins, and perhaps the best characterized class of PRRs. TLRs 1-6, 10 , and 11 are found in the plasma membrane and TLRs 3, 7, and 9 in endosomal membranes. While most TLRs have quite defined ligand targets (e.g., TLR 5 recognizes flagellin, TLR 7 recognizes single stranded RNA), TLR 2 and TLR 4 both recognize a wide range of ligands including high-mobility group box protein 1 (HMGB1), peptidoglycan, mucins, hemagglutinin, and porins for TLR 2; and lipopolysaccharide (LPS), vesicular stomatitis virus glycoprotein G, mannan, heat shock protein (HSP) 60, HSP 70, and HMGB1 for TLR 4 (24).

Studies in human fetal autopsy samples have detected the presence of TLRs from an early gestational age. Immunohistochemical studies have demonstrated TLR 3 expression in neuronal and glial 
cells in preterm brains from approximately 23 weeks' gestational age (28). Petrikin and colleagues used a PCR array platform validated by hydrolysis probe qPCR to analyze the temporal expression of TLRs in the human fetal lung at 60-, 90-, and 130-day gestational age. TLRs $1-8$ and 10 were identified in lung samples from 60 -day gestational age fetuses, indicating that TLR signaling is likely functional from very early in fetal development. Interestingly, with the exception of TLR 4, the expression of all TLR transcripts increased significantly (between 1.43- and 9.20-fold) from 60 to 130 days of gestation (29). Flow cytometry studies have demonstrated that TLR4 is expressed on the surface of CD $14^{+}$monocytes harvested from preterm infants delivered at $<30$ weeks' gestational age, although at levels significantly lower than that seen in preterm infants born later than 30 weeks' gestation. A similar pattern was identified for TLR4 mRNA transcripts in CD14 ${ }^{+}$monocytes (30). Increasing expression of TLR 2 in the lung with gestational age was identified in studies of fetal ovine TLR expression between 108 and 145-day gestational age (31). Again using qPCR, Sow et al. demonstrated the presence of mRNA transcripts for TLRs $4,5,7$, and 8 at 115-day gestational age in the fetal ovine lung (32).

Toll-like receptor expression has also been characterized in the fetal ovine skin and spleen across the second trimester of pregnancy; work by Nalubamba and co-workers suggests that TLRs 1-10 are expressed in the spleen at levels approaching or often exceeding that seen in the adult from 60 days of gestation (33). TLR expression in the fetal skin was also found to be extensive, although transcripts for TLRs 9 and 10 were not identified between 60 and 90 days of gestation (33). A recent study by Iram and colleagues reported that skin samples taken from embryonic (9-11 weeks' gestation) to fetal (12-13 weeks' gestation) autopsies expressed the same range of TLRs as adult skin. Their data also suggested that, mRNA transcripts for TLRs 1-5 were more highly expressed in these early gestation skin samples than in adult skin samples (34).

In summary, these studies provide strong evidence to suggest that in the developing fetus: (i) TLRs are expressed from very early in gestational development; (ii) TLR expression is widespread in both AF-exposed (lung, skin) and internal (brain, spleen, immunocytes) fetal tissues; and (iii) the ontological pattern of TLR expression likely varies between tissues, which, in turn, potentially impacts the ability of individual tissues to mount a response to tissue invasion and injury by microorganisms.

In the cytosol, retinoic acid-inducible gene 1 (RIG-1)-like helicases, including RIG-1 and melanoma differentiation-associated gene 5 (MDA5), detect double stranded viral RNA and play an important role in the regulation of interferon expression in response to viral infection $(35,36)$. Work in embryonic chickens indicates that MDA5 is expressed in both the fetal spleen and lung from at least embryonic day 10 (35). In studies utilizing primary fetal buffalo fibroblast cells, Poly I:C treatment resulted in significant increases in RIG-1, MDA-5, and interferon$\beta$ mRNA expression, suggesting that the presence of a functional innate immune response to simulated viral infection (36). RIG-1, MDA5, and interferon- $\beta 1$ mRNA transcripts have also been shown to be up-regulated in primary human cord blood mast cells in response to stimulation with antibody enhanced dengue virus infection (37). NOD-like receptors are a third class of PRRs; NOD-1 and NOD-2 recognize specific peptidoglycan derivatives (meso-diamino-pimelic acid and muramyl dipeptide, respectively) to initiate pro-inflammatory NF- $\mathrm{B}$ and MAP kinase signaling (38). Several other NOD-like receptors are implicated in multiple immunomodulatory roles including inflammasome function and type-I interferon production (27). A recent analysis of NOD-like receptor Nlrp6 inflammasome elements by Kempster and colleagues demonstrated that pycard, caspase-1, and IL-18 (an inflammasome substrate) mRNA transcripts are detectable in the fetal ovine jejunum at 100-day gestational age. In the same study, Nlrp6, pycard, and caspase-2 transcripts were detected in the fetal rat intestine and lung at both embryonic day 16 and 20 (39).

Considered together, these data from animal and human studies suggest that functional TLR, RIG-1-like helicase, and Nod-like receptor PRR systems are widely expressed from early in pregnancy (Table 1). As such, it appears reasonable to conclude that these innate immune system effectors are capable of playing a role in the fetal response to intrauterine infection.

\section{COMPLEMENT}

The complement system is a central component of the humoral innate immune system (40). To date, three pathways of

Table 1 | Summary of pattern-recognition receptor expression in human and animal fetal tissues

\begin{tabular}{|c|c|c|c|c|}
\hline \multirow[t]{2}{*}{ PRR class/type } & \multicolumn{3}{|c|}{ Fetal studies } & \multirow[t]{2}{*}{ Reference } \\
\hline & Component & Organism and tissue & Fetal gestational age (days) & \\
\hline \multirow[t]{6}{*}{ Toll-like receptors } & TLR3 & Human neuronal and glial cells & 161 & $(28)$ \\
\hline & TLRs $1-8$ and 10 & Human lung & 60 & $(29)$ \\
\hline & TLR2 & Ovine lung & 108 & $(31)$ \\
\hline & TLRs $4,5,7$, and 8 & Ovine lung & 115 & $(32)$ \\
\hline & TLRs 1-10 & Ovine spleen & 60 & (33) \\
\hline & TLRs 1-5 & Human skin & 84 & (34) \\
\hline RIG-1-like receptors & MDA5 & Avian spleen and lung & 10 & $(35)$ \\
\hline \multirow[t]{2}{*}{ NOD-like receptors } & Pycard, caspase-1, IL-18 & Ovine jejunum & 100 & (39) \\
\hline & NIrp6, Pycard, caspase-2 & Rodent intestine and lung & 16 & (39) \\
\hline
\end{tabular}


complement activation have been identified (i) the classical pathway, which is activated in response to antigen-antibody complex formation; (ii) the constitutively active, antibody-antigen complex independent alternative pathway; and (iii) a more recently identified lectin pathway, which is activated following the formation of complexes between mannin binding lectin and surface expressed microbial mannose (41). Cleavage of C3 into C3a and C3b is a key step in complement activation common to all three activation pathways. $\mathrm{C} 3 \mathrm{~b}$ is a multifunctional complement mediator; it binds foreign cells, identifying them for phagocytosis. In addition, C3b interacts with C5 to initiate a cleavage cascade that results in the formation of a lytic membrane attack complex that damages the membrane integrity of foreign cells (41). Complement proteins also have a range of innate immunomodulatory functions (42); for example, $\mathrm{C} 5 \mathrm{a}$ and $\mathrm{C} 3 \mathrm{a}$ act as chemoattractants via interactions with CD88 and C5L2 receptors, recruiting immunocytes (including lymphocytes and neutrophils) to sites of microbial invasion or localized inflammation (40).

Although much remains to be understood in relation to the ontogeny of fetal complement expression, there are a number of clinical studies that demonstrate elements of the complement system are expressed from early in gestation $(40,43)$. At term, serum complement factors' concentrations have been reported to range from 36 to $79 \%$ of normal adult levels (44). As summarized by Grumach et al., complement pathway components are detectable as early as 5 weeks' gestation. The authors note that (p. 267), "one may assume that all the components may be detected by week 18-20 of pregnancy" (43). $\mathrm{CH}_{50}$ (a sheep erythrocyte-based lysis assay to determine the functional activity of the classical and terminal complement pathways) studies with preterm infants suggest that functional complement activity at 27-31 weeks of gestation is approximately one-third of the normal adult level $(40,45)$. Woolach and colleagues reported an $\mathrm{AP}_{50}$ (a rabbit erythrocytebased lysis assay that employs a calcium chelator to inactivate the classical and lectin pathways to isolate alternative pathway functional activity) value of approximately 50\% normal adult levels for preterm infants born between 28 and 33 weeks' gestation (44). A similar pattern is apparent in fetal sheep. Analysis of data from modified $\mathrm{CH}_{50}$ assays using serum from fetuses delivered at 125day (term is between 145 and 150 days) revealed a pattern of lytic activity similar to that of maternal sheep serum. In contrast, maximum lysis using serum from earlier gestational ages (85 and 95 days) was approximately twofold lower (46).

Together, these data suggest that the fetus is equipped with a functional complement system from early in gestation, although it is active at lower levels than in adults.

\section{DEFENSINS}

Defensins are a class of antimicrobial proteins that are released from a variety of cell types in response to the detection of tissue injury or microbial pathogens. They are found at highest concentrations in cells that play a role in host defense including leukocytes (where they are stored in granules) and Paneth cells in the small intestine. Defensins are also produced by a range of epithelial cells, either constitutively or following stimulation by microbial agonist (47). Human beings have six $\alpha$-defensins $(\mathrm{H} \alpha \mathrm{D})$ and at least 28 $\beta$-defensins (H $\beta D)$, although only $H \beta D$ 1-6 and 23 have been well characterized (26). H $\alpha \mathrm{D}$ 1-4 are commonly termed human neutrophil peptide (HNP) 1-4 due to their constitutive synthesis by neutrophil precursors in bone marrow (47). H $\alpha \mathrm{D} 5$ and 6 are commonly termed human defensins (HD) 5 and 6 . They are expressed by intestinal cells in addition to a number of types of epithelial cells. In mammals, epithelial cells are the primary sources of $\mathrm{H} \beta \mathrm{Ds}$ (26).

As elegantly reviewed by Yang and colleagues, defensins play a multitude roles in host defense. Both $\mathrm{H} \alpha \mathrm{Ds}$ and $\mathrm{H} \beta \mathrm{D}$ s exhibit differential microbiocidal activity by the formation of pore-like structures in microbial cell membranes, resulting in membrane disruption and depolarization (47). H $\beta D 1$ and H $\beta$ D 2, for example, are effective at killing Escherichia coli and Pseudomonas aerug-

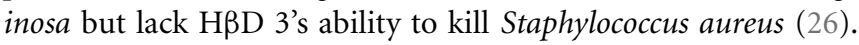
Defensins have also been shown to have anti-viral activity, can neutralize microbial toxins, and act as both chemoattractants and activators of phagocytic activity. Importantly, they have also been shown to mobilize dendritic cells and T-lymphocytes, bridging the innate and adaptive immune responses to combat infection (26). Given their importance to host microbial defense, a number of investigators have undertaken studies in human beings and animals in an attempt to clarify the ontological development of fetal defensin expression across gestation.

A mounting body of evidence exists to suggest that defensins are expressed early in gestation across a wide range of organisms. Isoforms of the $\beta$-defensin-like gene have been identified in an expressed sequence tag library derived from the early developmental stages of the olive flounder, Paralichthys olivaceus (48). Working with fertilized chick eggs over a 12-day time course, Meade and co-workers demonstrated the expression of 13 avian $\beta$-defensins at 3 -day post-laying. Interestingly, differing patterns of both temporal and spatial (head vs. abdomen) expression were evident in the magnitude of avian $\beta$-defensin expression over the 12-day time course, suggesting that a process of developmental regulation with embryonic development (49). Data from a more recent histological study using immunolabelling suggest that peridermal granules in the developing embryonic chick skin contain avian $\beta$-defensin 9 , indicating that these organelles play a role in both host defense and epidermal barrier formation (50). In sheep fetuses, initial work by Huttner et al. demonstrated the presence of ovine $\beta D 1$ and $\beta D 2$ mRNA transcripts in jejunum, ileum, caecum, and colon of 130-day gestational age fetuses (51). These findings were later replicated, in part, by work undertaken in late gestation (120-140-day gestational age) sheep fetuses, with Meyerholz and colleagues reporting the identification of ovine $\beta \mathrm{D} 2$ expression in both the small and large intestine (52).

Data from human fetal studies also suggest that a pattern of spatial and temporal regulation for defensins. Using semiquantitiative PCR, Starner et al. demonstrated that H $\beta D 1, H \beta D 2$, but not $\mathrm{H} \beta \mathrm{D} 3$ were expressed in the fetal lung at 42 weeks' gestational age; all three $\mathrm{H} \beta \mathrm{D}$ s were undetectable at 18 and 22 weeks of gestation. Interestingly, the human cathelicidin, LL-37, was found to be expressed at all three gestational time points, with the highest apparent expression at 18 weeks' gestation (53). A distinct pattern of defensin expression is also apparent in the fetal skin. Immunohistochemical studies have shown that $\mathrm{H} \beta \mathrm{D} 2$ and $\mathrm{H} \beta \mathrm{D} 3$ staining is absent from the fetal skin at $10-15$ weeks of gestational 
age, and that H $\beta \mathrm{D} 3$ is expressed in the stratum corneum at 1824 weeks' gestation (54). In vitro studies with primary human fetal keratinocytes suggest that $\mathrm{H} \beta \mathrm{D} 1$ and $\mathrm{H} \beta \mathrm{D} 2$ mRNA is often more highly expressed at 22 weeks' gestation than in samples from neonatal and adult skin (55). Defensin proteins have also been identified in human amniotic fluid and vernix caesosa samples from term pregnancies without chorioamnionitis and in the amniotic fluid of women with preterm labor $(56,57)$.

\section{FETUS, INFECTION, AND INTRAUTERINE INFLAMMATION}

Fetal inflammation is strongly associated with impending preterm labor, preterm prelabor rupture of membranes (PPROM) and is also an independent risk factor for subsequent neonatal morbidity (58). Elevated levels of cord blood IL-6 at birth have, for example, been demonstrated to predict the development of bronchopulmonary dysplasia (59). In a now classic study, Gomez and colleagues proposed that a fetal cord blood plasma IL- 6 concentration in excess of $11 \mathrm{pg} / \mathrm{mL}$ was indicative of a FIRS, a condition that the authors describe as being (p. 201) "frequently associated with microbial invasion of the amniotic cavity" (58).

Intrauterine infection is associated with chorioamnionitis and funisitis, which are, in turn, inversely related to gestational age at delivery $(16,60)$. To further investigate the relationship between intrauterine infection and fetal inflammation, Yoon and colleagues examined putative relationships between umbilical cord blood IL6 concentration, funisitis, amniotic-fluid microbial culture, and neonatal sepsis in a cohort of 315 preterm (20-35 weeks' gestation) infants. The presence of oligohydramnios, which is associated with a range of neonatal morbidities, has also been associated with elevated cord blood IL-6 concentrations in women with PPROM (61). Preterm infants with funisitis were found to have elevated rates of chorioamnionitis and positive amniotic-fluid cultures, a lower gestational age at delivery, and higher cord blood IL-6 concentrations than those without funisitis. These data suggest that funisitis is also associated with a FIRS (60). Fetal plasma IL-6 levels have also been shown to be significantly associated with inflammatory lesions in the chorioamnion, leading to the conclusion that funisitis and chorioamnionitis are histological markers of FIRS (62).

Interestingly, subsequent work by Lee et al. demonstrated that, in an analysis of patients with intrauterine inflammation (defined on the basis of an elevated matrix metalloproteinase 8 concentration in the amniotic fluid), cord blood plasma C-reactive protein was lower in the absence of proven amniotic-fluid infection, compared to cases where infection was confirmed by culture. These data suggest that although FIRS is possible in the absence of intraamniotic infection, the strongest fetal inflammatory response is associated with a culturable amniotic infection (63). Recent studies suggest that rather than having a simple binary relationship, it is important to take into account the magnitude of amniotic-fluid inflammation when predicting pregnancy outcomes (64). On the basis of these data, it is also tempting to speculate that a similar pattern may be applicable with regards to cord blood plasma IL-6 levels and the severity of FIRS.

Much remains to be understood regarding the differential impact of intraamniotic infection with differing microorganisms (either in isolation or simultaneously with one or more other microorganisms) on the systemic fetal inflammatory response; Lee and colleagues, for example, noted the isolation of some 11 species of microorganisms from the amniotic cavity and identified polymicrobial infections in 6 out of 89 cases (63). Similar findings suggesting that the involvement of a wide range of microbial species and a significant proportion of polymicrobial infections of the amniotic environment have been reported by both DiGiulio and Jones $(17,65)$.

How the presence of multiple immunomodulatory microbial agonists alters fetal inflammatory signaling in utero is still imprecisely understood. Based on the observations that (i) intrauterine inflammation is elevated in preterm compared to term labor; (ii) culture positive amniotic-fluid infection is associated with more severe fetal inflammatory responses; and (iii) polymicrobial infections are more common in labor at earlier gestations, one might be tempted to conclude that a polymicrobial infection would equate to a more severe inflammatory response. However, data, to date, suggest that the intrauterine inflammatory response is likely influenced by (at least) the magnitude and timing of microbial agonist exposure. The immunomodulatory effects of one microorganism, perhaps by down-regulating antimicrobial peptide expression as has been shown by Ureaplasma spp., may allow for additional microorganisms to establish in utero (66). It is also possible that the pathogen-specific inflammatory responses of different microorganisms combine to trigger multiple signaling pathways required to initiate preterm labor (67).

Findings from in vitro studies with preterm and term human monocytes, for example, suggested that Ureaplasma urealyticum exposure modified the pro-inflammatory response to a subsequent stimulation with E. coli LPS over a $24 \mathrm{~h}$ time course, and did so in a dose-dependent fashion. Exposure to a high dose $\left(10^{6}\right.$ color change units) of $U$. urealyticum enhanced the release of TNF- $\alpha$ and IL-8, but not IL- 6 and IL-10 (68). The authors speculated that the basis of the enhanced pro-inflammatory response was due to the differential suppression of regulatory cytokine (e.g., IL-10) expression. Evidence of an interaction between U. parvum and LPS is also provided by work in a sheep model of intrauterine infection. Chronic (70 days) but not acute (7 days) U. parvum exposure has been shown to inhibit pro-inflammatory signaling in the fetal lung (69). Surprisingly, acute U. parvum exposure was subsequently reported to have an LPS-inhibitory effect in the chorioamnion, suggesting that agonist, exposure timing, and tissue all impact inflammation deriving from intrauterine infection (70).

Data from clinical studies that suggest a fetal inflammatory response to direct stimulation by microbial agonist are supported by a number of studies undertaken in non-human primate, sheep, rabbit, and rodent models of human pregnancy. With the ability to control dose, type of exposure, and length of exposure, animal models of intrauterine infection have been important in advancing our understanding of the fetal inflammatory response to different microbial agonists.

Working with an ascending model of intrauterine infection in rabbits, Yoon et al. demonstrated that cervical inoculation of $10^{3}-10^{4}$ colony forming units of $E$. coli resulted in white matter injury in pups euthanized 5-6 days after inoculation (71). Subsequent studies in a similar model system investigated the acute intrauterine responses to $E$. coli intrauteruine infection. Over a 
$30 \mathrm{~h}$ time course, progressive histologic inflammation was identified in the uterus, placenta, and lung (72). Interestingly, although mitotic activity in the pup brain was found to be retarded after $8 \mathrm{~h}$ post-inoculation, there was no evidence of brain inflammation or apoptosis suggesting that a potential lag in the transduction of inflammation from an infection of the amniotic fluid. The effects of intraamniotic E. coli LPS exposure have also been extensively characterized in the sheep using ultrasound-guided intraamniotic injections. LPS exposure has been shown to result in time and dose-dependent inflammatory responses in the chorioamnion, systemic fetal inflammation, changes in fetal lung development, and fetal brain inflammation (73-77).

Although E. coli and E. coli LPS serve as useful reagents for studying intrauterine inflammatory responses, E. coli infection in the setting of preterm delivery is comparatively uncommon. In contrast, the Ureaplasma spp., and especially U. parvum, are among the microorganisms most commonly identified by culture or PCR in cases of PTB. Intraamniotic inoculation of chronically catheterized macaques with clinical isolates of $U$. parvum serovar 1 or $M$. hominis resulted in significant increases in amnioticfluid leukocytes within $24 \mathrm{~h}$ and amniotic-fluid TNF- $\alpha$, IL- $1 \beta$, Il-6, IL- 8 between 48 and $72 \mathrm{~h}$ post-inoculation (78). Studies with group B streptococci in similarly catheterized macaques revealed increases in amniotic-fluid IL- $1 \alpha$ and IL- 6 at $15-18 \mathrm{~h}$ post inoculation, substantially earlier than that seen in response to intrauterine infection with U. parvum, suggesting that a differential inflammatory response to microbial agonist (78). Studies undertaken in the chronically infected sheep further underscore the pro-inflammatory role U. parvum in pregnancy; intrauterine U. parvum infection has been shown to be associated with a progressive chorioamnionitis, changes in fetal growth and fetal inflammation (79-81).

As summarized above, there is now ample evidence from clinical and animal studies to demonstrate that infection of the uterus is associated with intrauterine inflammation, and that the fetus is well equipped to respond to such infection with a robust proinflammatory response. Accordingly, it is of interest to determine the origins of this intrauterine inflammatory process in order to assist in our understanding of the pathological processes underpinning infection-associated PTB and our attempts to develop targeted interventions.

In many cases, it appears that fetal bacteremia is less common than colonization or infection of gestational tissues such as the placenta or the amniotic fluid. Recent studies in sheep, for example, demonstrated that fetal U. parvum bacteremia is uncommon despite the presence of viable microorganisms in the amniotic fluid (82). It is unclear, however, whether fastidious microorganisms such as $U$. parvum have the ability to replicate in amniotic fluid or if they are seeded into it following growth on amniotic-fluid exposed tissues.

A study investigating the acute fetal responses to intraamniotic Candida albicans infection demonstrated an absence of fungal RNA in the fetal ovine spleen in conjunction with positive amniotic-fluid cultures and the detection of C. albicans RNA in the fetal lung and skin (20). Similarly, in findings from the Alabama preterm birth study, placental cultures for M. hominis and/or $U$. parvum were positive in $63.4 \%$ of male fetuses. In contrast, only
$27.6 \%$ of fetuses had positive cord blood cultures (83). For future studies, it will be of particular interest to determine how modifiable factors including gestational age, length of infection, and the infectious organism itself interact to influence the prevalence of fetal bacteremia in infection-associated PTB.

There is also evidence to suggest that pro-inflammatory microbial agonists in the amniotic fluid, such as LPS, does not passively diffuse across cell layers (84). These findings go some way to explaining the observation that while $1 \mu \mathrm{g} / \mathrm{kg}$ is considered a sublethal intravenous bolus dose of E. coli LPS in the sheep fetus, it is possible to inject in excess of $10 \mathrm{mg} E$. coli LPS into the amniotic fluid of pregnant ewes without causing fetal death $(74,85$, 86). Interestingly, the intraamniotic administration of LPS from other Gram negative microorganisms associated with PTB has been shown to have a much more severe impact on fetal wellbeing, although it is unclear if this relates to a more toxic inflammatory response or enhanced ability to penetrate the fetal circulation. Studies in a sheep model of pregnancy, for example, have shown that Porphyromonas gingivalis LPS exposure results in much higher rates of fetal death than E. coli LPS (87). A recent analysis of human fetal membrane responses to PTB-associated microorganisms provides further evidence for an organism-specific and host-specific inflammatory effects deriving from the presence of microorganisms in the amniotic fluid. Peltier and colleagues demonstrated that PTB-associated pathogens including E. coli, Gardnerella vaginalis, Group B streptococci, and Ureaplasma spp. elicited differing pro-inflammatory responses in human fetal membrane explant studies. For example, G. vaginalis stimulated IL- $1 \beta$ and TNF- $\alpha$ production, whereas $U$. parvum elicited IL-10 and TNF- $\alpha$ expression but had no effect on the concentration of IL-1 $\beta$ (88). These data suggest that tissues directly exposed to the amniotic fluid are likely key in the propagation of amniotic-fluid inflammation in response to intrauterine infection and likely also contribute to systemic fetal inflammation. With this in mind, the remainder of this paper will discuss evidence for the contribution of the fetal lung, skin, and gastrointestinal tract to intrauterine inflammation.

\section{CONTRIBUTION OF FETAL LUNG, SKIN, AND GASTROINTESTINAL TRACT TO INTRAUTERINE INFLAMMATION}

Inflammation in the fetal lung in response to microorganisms in the amniotic environment has been a subject of significant interest for several decades and the primary focus of fetal inflammation in association with PTB (89). Broadly speaking, work in this area may be classified into two broad avenues of investigation: (i) the localized impact of intrauterine infection on the lung itself, including structural $(90,91)$, functional (92), and inflammatory adaptations $(73,76,93)$; and (ii) the extra-pulmonary effects of inflammation in the fetal lung, including changes in fetal systemic inflammation (94-96), immunocyte reactivity (97-99), and amniotic-fluid inflammation (100).

The fetal lung has been shown to generate a pro-inflammatory response following exposure to a wide range of microbial agents including adenovirus $(101,102)$, E. coli LPS $(73,103,104)$, Ureaplasma spp. (81, 105), and C. albicans (20), which is in keeping with studies suggesting that the developing fetal lung expresses a wide range of PRRs from early in gestation (29). Human lung 
cells have also been shown to express complement factors, but not defensins, in response to endotoxin exposure $(103,106)$. Infection with $C$. albicans elicits an exceptionally vigorous inflammatory response in the fetal lung, but a much milder response in the chorioamnion (20). In comparison, the response elicited by Ureaplasma spp. is much more mild with to regards fetal lung inflammation (105). It is also hypothesized that signaling by pro-inflammatory cytokines plays a key role in driving lung maturation. Evidence in support of this model have been provided by studies in the sheep, wherein LPS-driven inflammation in the chorioamnion (occurring as early as $5 \mathrm{~h}$ after intraamniotic LPS injection) and lung (occurring 1-2 days after intraamniotic LPS injection) preceded lung maturation by as much as 5 days.

A number of cytokines have also been shown to exert differential effects on the fetal lung. Increases in a range of cytokines including IL-1, IL-6, IL-8, and TNF- $\alpha$ in the amniotic fluid and fetal lung are associated with intrauterine infection and preterm labor (107). Interestingly, work in a sheep model of pregnancy demonstrated that intraamniotic IL-8 exposure resulted in only small increases in bronchoalveolar lavage immunocytes and did not induce lung maturation (108). A similarly small response in the lung was identified following exposure to TNF- $\alpha$ (109).

In contrast, IL- $1 \alpha$ and IL- $1 \beta$ both elicit marked proinflammatory and maturational effects on the fetal ovine lung, with IL- $1 \alpha$ driving the strongest response (110). IL- $1 \alpha$ has also been shown to elicit a dose-dependent increase in surfactant protein-A and protein-B mRNA expression in rabbits (111). Subsequent work by Sosenko et al. suggested that the pulmonary effects identified in association with intraamniotic IL- $1 \alpha$ result from direct contact with the fetal lung (112). These observations may hint at a potential role for the lung in amplifying IL-1 inflammatory responses derived from the fetal membranes, skin, or gut, as well as acting as a transducer of intraamniotic inflammation to systemic fetal inflammation.

The role played by the lung in contributing to extra-pulmonary inflammation is of particular interest given the strong association between FIRS, PTB, and neonatal morbidities including bronchopulmonary dysplasia and white matter injury. Between 85 and 115 days' gestation, the ovine fetal lung produces lung fluid at a rate of $2-3 \mathrm{~mL} / \mathrm{kg} / \mathrm{h}$ and it is estimated that $50 \%$ of that volume is excreted into the amniotic fluid with a mixing time of $2-3 \mathrm{~h}(113,114)$. As noted in seminal work by Tomoda et al., the fetus is estimated to swallow amniotic fluid at a substantial rate, with reported daily volumes varying between 200 and $1000 \mathrm{~mL}$ (115). In fetal sheep, E. coli LPS has been reportedly detected in the fetal stomach 2 days after intraamniotic exposure (116). As such, it seems likely that pro-inflammatory mediators excreted by the pulmonary epithelium would rapidly make their way into the amniotic fluid, where they could interact with immunocytes in the amniotic fluid, the fetal skin and membranes, and, after swallowing, the fetal gastrointestinal epithelium. Although the relative contributions of tissues amniotic-fluid inflammation remain unclear, it seems likely that the lung is an important source of inflammatory cytokines and white blood cells. Using polymyxin$B$ to bind and inhibit the inflammatory activity of intraamniotic E. coli LPS, Saito and colleagues demonstrated that a reduction in fetal lung mRNA expression was associated with significant reductions in cytokine protein concentration in the amniotic fluid (100).

In clinical studies, elevated white blood cell counts in the amniotic fluid are associated with intrauterine infection and an increased risk of spontaneous preterm delivery $(117,118)$. A significant majority of the leukocytes found in the amniotic fluid in association with intrauterine inflammation are of fetal origin (119). It is tempting to speculate that the lung is a likely source of leukocytes in the amniotic fluid, although it is possible that cells migrate across the gastrointestinal epithelium and developing skin in response to a chemotactic gradient. Indeed, Payne and colleagues have recently demonstrated the presence of clusters of basophilic cells in the apical layers of the developing fetal skin in response to experimental C. albicans infection (20). In human neonates, prolonged rupture of membranes during pregnancy has been associated with elevated white blood cells and IL-6 in bronchoalveloar lavage samples taken within $24 \mathrm{~h}$ of delivery (120). Similarly, infants with funisitis born prior to 28 weeks' gestation were found to have higher levels of $\mathrm{CD}^{+} 8^{+}$cells in tracheobronchial aspirate fluid taken within $24 \mathrm{~h}$ of delivery than those without funisitis (121). Sheep infected with intraamniotic $U$. parvum serovar 3 were also shown to have statistically significant increases in bronchoalveolar neutrophils after 3 days of exposure (105).

Although the lung has been the major focus of fetal inflammatory responses to intrauterine inflammation, there is evidence to suggest that the fetal skin and gastrointestinal tract also generate a pro-inflammatory response following exposure to microbial agonists. In a fetal autopsy study, Kim and colleagues demonstrated fetal skin inflammation and TLR-2 regulation in association with microbial invasion of the amniotic cavity, concluding that dermatitis is a component of the FIRS (122). Subsequent studies in sheep have demonstrated that the intraamniotic injection of either E. coli LPS, U. parvum serovar 3 or C. albicans results in a proinflammatory response in the skin, with $C$. albicans eliciting the strongest response $(20,74,79,123)$. T-cells (present in the second trimester), mast cells (present from 12 weeks' estimated gestation), and antigen presenting cells (present from at least 9 weeks' estimated gestation) have been identified in the developing human dermis from early in fetal life (124). Fetal keratincoytes have been shown to respond directly to stimulation with microbial agonist and are known to express a wide range of antimicrobial peptides $(55,100,125,126)$. In the developing fetal gut, endotoxin exposure in preterm sheep is associated with disrupted structural development of the intestinal epithelium. Although an inflammatory response was not evident at 2 days after endotoxin administration, significant infiltrations of T-lymphocytes and myeloperoxidase cells were detected at 14 days-post exposure (116). These data suggest that a temporally different response in the fetal gut to inflammatory agonist when compared to more acute responses identified in the fetal lung and skin. Subsequent work, again in the fetal sheep, has suggested that a critical role for IL- $1 \alpha$ in these gutmodifying processes, reminiscent of earlier data showing a similar role for IL- $1 \alpha$ in the fetal ovine lung $(110,127)$.

With regards to systemic fetal inflammation, the available data suggest that the lung is likely a key mediator of transducing 
inflammatory signaling from the amniotic fluid to the internal fetal organs and the fetal gastrointestinal tract $(94,96,128)$. Although inflammation of the fetal lung has been demonstrated to induce systemic responses and cause inflammation in the fetal gut, exposure of the fetal skin and amnion to similar stimulation did not result in detectable inflammation in the lung or the gut $(94,96)$. However, it does appear that both the fetal skin and fetal gut play a smaller contributing role to the overall induction of FIRS $(94,128)$. Kramer et al. demonstrated a differential systemic fetal inflammatory response to acute E. coli LPS exposure, which was dependent on the fetal organs stimulated with agonist (128). Kemp and colleagues subsequently demonstrated that acutely exposing the fetal lung to $E$. coli LPS resulted in increased IL1- $\beta$, IL-6, and IL- 8 mRNA in the fetal spleen, increased cord blood plasma MCP-1, and elevated cord blood white blood cell counts. Smaller changes were identified in response to fetal skin and amnion exposure, but not in response to acute gut exposure $(94,96)$. These data are also in keeping with previous studies that suggest a longer inflammatory response time for the fetal gastrointestinal tract compared to the skin or lung. Underscoring the complexity of intrauterine inflammatory signaling, these data also point to a differential temporal and spatial response to fetal inflammatory stimulation that likely varies with the microbial agonist in question.

\section{CONCLUSION}

As a function of PTB, the contribution of the fetus to intrauterine inflammation and FIRS is complex and, based on the evidence presented herein, likely dependent on a wide range of modifying factors. Evidence is available to suggest that gestational age at the time of infection, the nature of the infection itself (single organism vs. polymicrobial infection), the host's genetic background in addition to differences in specific tissue responses each combine to impact the origins and development of the intrauterine inflammation associated with PTB. It is clear, however, that the fetus is well endowed with the immunological armamentarium necessary to respond to microbial invasion of the amniotic fluid. Moreover, we now know that the fetus possesses the ability to recognize and respond to microbial agonist via elements of the innate immune system from comparatively early in gestation.

There is a compelling body of evidence from basic science and clinical studies to demonstrate that intrauterine infection is strongly associated with fetal inflammation. There is also excellent data to suggest that the intrauterine inflammation that is implicated in the precocious initiation of labor also plays a role in the development of a number of the congenital pathologies that are commonly identified in preterm infants, such as bronchopulmonary dysplasia and white matter injury. Accordingly, identifying the spatio-temporal origins of intrauterine inflammation, and how it might differ on an individual, case-by-case basis, is likely an important requirement in our efforts to develop treatments that prevent PTB while ensuring the continued development of a healthy fetus.

\section{ACKNOWLEDGMENTS}

Matthew W. Kemp is supported by The Women and Infants Research Foundation (Perth, WA, Australia).

\section{REFERENCES}

1. WHO. Manual of the International Statistical Classification of Diseases, Injuries, and Causes of Death. Geneva: World Health Organisation (1975).

2. Kramer MS, Papageorghiou A, Culhane J, Bhutta Z, Goldenberg RL, Gravett $\mathrm{M}$, et al. Challenges in defining and classifying the preterm birth syndrome. Am J Obstet Gynecol (2012) 206(2):108-12. doi:10.1016/j.ajog.2011.10.864

3. Gotsch F, Romero R, Erez O, Vaisbuch E, Kusanovic JP, Mazaki-Tovi S, et al. The preterm parturition syndrome and its implications for understanding the biology, risk assessment, diagnosis, treatment and prevention of preterm birth. J Matern Fetal Neonatal Med (2009) 22(Suppl2):5-23. doi:10.1080/14767050902860690

4. Goldenberg RL, Gravett MG, Iams J, Papageorghiou AT, Waller SA, Kramer M, et al. The preterm birth syndrome: issues to consider in creating a classification system. Am J Obstet Gynecol (2012) 206(2):113-8. doi:10.1016/j.ajog.2011.10. 865

5. Villar J, Papageorghiou AT, Knight HE, Gravett MG, Iams J, Waller SA, et al. The preterm birth syndrome: a prototype phenotypic classification. Am JObstet Gynecol (2012) 206(2):119-23. doi:10.1016/j.ajog.2011.10.866

6. Menon R, Dunlop AL, Kramer MR, Fortunato SJ, Hogue CJ. An overview of racial disparities in preterm birth rates: caused by infection or inflammatory response? Acta Obstet Gynecol Scand (2011) 90(12):1325-31. doi:10.1111/j. 1600-0412.2011.01135.x

7. Academies IoMotN. Preterm Birth: Causes, Consequences and Prevention. Report Brief. Washington DC: Institute of Medicine of the National Academies (2006).

8. Lawn JE, Kerber K, Enweronu-Laryea C, Cousens S. 3.6 Million neonatal deaths-what is progressing and what is not? Semin Perinatol (2010) 34(6):371-86. doi:10.1053/j.semperi.2010.09.011

9. Howson CP, Kinney MV, McDougall L, Lawn JE. Born toon soon: preterm birth matters. Reprod Health (2013) 10(Suppl 1):1-9. doi:10.1186/1742-4755$10-\mathrm{S} 1-\mathrm{S} 1$

10. Chang HH, Larson J, Blencowe H, Spong CY, Howson CP, Cairns-Smith S, et al. Preventing preterm births: analysis of trends and potential reductions with interventions in 39 countries with very high human development index. Lancet (2013) 381(9862):223-34. doi:10.1016/S0140-6736(12)61856-X

11. Goldenberg RL, Culhane JF, Iams JD, Romero R. Epidemiology and causes of preterm birth. Lancet (2008) 371(9606):75-84. doi:10.1016/S0140-6736(08) 60074-4

12. Romero R, Espinoza J, Kusanovic JP, Gotsch F, Hassan S, Erez O, et al. The preterm parturition syndrome. BJOG (2006) 113(Suppl 3):17-42. doi:10.1111/ j.1471-0528.2006.01120.x

13. Rinaldi SF, Hutchinson JL, Rossi AG, Norman JE. Anti-inflammatory mediators as physiological and pharmacological regulators of parturition. Expert Rev Clin Immunol (2011) 7(5):675-96. doi:10.1586/eci.11.58

14. Challis JR, Lockwood CJ, Myatt L, Norman JE, Strauss JF III, Petraglia F. Inflammation and pregnancy. Reprod Sci (2009) 16(2):206-15. doi:10.1177/ 1933719108329095

15. Polese B, Gridelet V, Araklioti E, Martens H, d'Hauterive SP, Geenen V. The endocrine milieu and $\mathrm{CD} 4 \mathrm{~T}$-lymphocyte polarization during pregnancy. Front Endocrinol (2014) 5. doi:10.3389/fendo.2014.00106

16. Lahra MM, Jeffery HE. A fetal response to chorioamnionitis is associated with early survival after preterm birth. Am J Obstet Gynecol (2004) 190(1):147-51. doi:10.1016/j.ajog.2003.07.012

17. Jones HE, Harris KA, Azizia M, Bank L, Carpenter B, Hartley JC, et al. Differing prevalence and diversity of bacterial species in fetal membranes from very preterm and term labor. PLoS One (2009) 4(12):1-9. doi:10.1371/journal. pone.0008205

18. DiGiulio DB. Diversity of microbes in amniotic fluid. Semin Fetal Neonatal Med (2012) 17(1):2-11. doi:10.1016/j.siny.2011.10.001

19. Bean LM, Jackson JR, Dobak WJ, Beiswenger TR, Thorp JA. Intra-amniotic fluconazole therapy for Candida albicans intra-amniotic infection. Obstet Gynecol (2013) 121(2 Pt 2):452-4. doi:10.1097/AOG.0b013e31827566ca

20. Payne MS, Kemp MW, Kallapur SG, Kannan PS, Saito M, Miura Y, et al. Intrauterine Candida albicans infection elicits severe inflammation in fetal sheep. Pediatr Res (2014) 75(6):716-22. doi:10.1038/pr.2014.35

21. Miura Y, Payne MS, Keelan JA, Noe A, Carter S, Watts R, et al. Maternal intravenous treatment with either azithromycin or solithromycin clears Ureaplasma parvum from the amniotic fluid in an ovine model of intrauterine infection. Antimicrob Agents Chemother (2014) 58(9):5413-20. doi:10.1128/ AAC.03187-14 
22. Kapetanovic R, Cavaillon JM. Early events in innate immunity in the recognition of microbial pathogens. Expert Opin Biol Ther (2007) 7(6):907-18. doi:10.1517/14712598.7.6.907

23. Zipfel PF, Skerka C. Complement regulators and inhibitory proteins. Nat Rev Immunol (2009) 9(10):729-40. doi:10.1038/nri2620

24. Lee CC, Avalos AM, Ploegh HL. Accessory molecules for toll-like receptors and their function. Nat Rev Immunol (2012) 12(3):168-79. doi:10.1038/nri3151

25. Philpott DJ, Sorbara MT, Robertson SJ, Croitoru K, Girardin SE. NOD proteins: regulators of inflammation in health and disease. Nat Rev Immunol (2014) 14(1):9-23. doi:10.1038/nri3565

26. Yang D, Liu ZH, Tewary P, Chen Q, de la Rosa G. Oppenheim JJ defensin participation in innate and adaptive immunity. Curr Pharm Des (2007) 13(30):3131-9. doi:10.2174/138161207782110453

27. Blander JM, Sander LE. Beyond pattern recognition: five immune checkpoints for scaling the microbial threat. Nat Rev Immunol (2012) 12(3):215-25. doi:10.1038/nri3167

28. Vontell R, Supramaniam V, Thornton C, Wyatt-Ashmead J, Mallard C, Gressens $\mathrm{P}$, et al. Toll-like receptor 3 expression in Glia and neurons alters in response to white matter injury in preterm infants. Dev Neurosci (2013) 35(2-3):130-9. doi:10.1159/000346158

29. Petrikin JE, Gaedigk R, Leeder JS, Truog WE. Selective toll-like receptor expression in human fetal lung. Pediatr Res (2010) 68(4):335-8. doi:10.1203/ 00006450-201011001-00656

30. Förster-Waldl E, Sadeghi K, Tamandl D, Gerhold B, Hallwirth U, Rohrmeister $\mathrm{K}$, et al. Monocyte toll-like receptor 4 expression and LPS-induced cytokine production increase during gestational aging. Pediatr Res (2005) 58(1):121-4. doi:10.1203/01.PDR.0000163397.53466.0F

31. Hillman NH, Moss TJM, Nitsos I, Kramer BW, Bachurski CJ, Ikegami M, et al. Toll-like receptors and agonist responses in the developing fetal sheep lung. Pediatr Res (2008) 63(4):388-93. doi:10.1203/PDR.0b013e3181647b3a

32. Sow FB, Gallup JM, Derscheid R, Krishnan S, Ackermann MR. Ontogeny of the immune response in the ovine lung. Immunol Invest (2012) 41(3):304-16. doi:10.3109/08820139.2011.631657

33. Nalubamba KS, Gossner AG, Dalziel RG, Hopkins J. Differential expression of pattern recognition receptors during the development of foetal sheep. Dev Comp Immunol (2008) 32(7):869-74. doi:10.1016/j.dci.2007.12.007

34. Iram N, Mildner M, Prior M, Petzelbauer P, Fiala C, Hacker S, et al. Age-related changes in expression and function of toll-like receptors in human skin. Development (2012) 139(22):4210-9. doi:10.1242/dev.083477

35. Karpala AJ, Bagnaud-Baule A, Goossens KE, Lowenthal JW, Bean AGD. Ontogeny of the interferon system in chickens. J Reprod Immunol (2012) 94(2):169-74. doi:10.1016/j.jri.2012.02.008

36. Singh M, Brahma B, Maharana J, Patra MC, Kumar S, Mishra P, et al. Insight into buffalo (Bubalus bubalis) RIG1 and MDA5 receptors: a comparative study on dsRNA recognition and in-vitro antiviral response. PLoS One (2014) 9(2). doi:10.1371/journal.pone.0089788

37. Brown MG, McAlpine SM, Huang YY, Haidl ID, Al-Afif A, Marshall JS, et al. RNA sensors enable human mast cell anti-viral chemokine production and IFN-mediated protection in response to antibody-enhanced dengue virus infection. PLoS One (2012) 7(3):1-11. doi:10.1371/journal.pone.0034055

38. Kim HS, Shin TH, Yang SR, Seo MS, Kim DJ, Kang SK, et al. Implication of NOD1 and NOD2 for the differentiation of multipotent mesenchymal stem cells derived from human umbilical cord blood. PLoS One (2010) 5(10):1855-63. doi:10.1371/journal.pone.0015369

39. Kempster SL, Belteki G, Forhead AJ, Fowden AL, Catalano RD, Lam BY, et al. Developmental control of the Nlrp6 inflammasome and a substrate, IL18, in mammalian intestine. Am J Physiol Gastrointest Liver Physiol (2011) 300(2):G253-63. doi:10.1152/ajpgi.00397.2010

40. McGreal EP, Hearne K, Spiller OB. Off to a slow start: under-development of the complement system in term newborns is more substantial following premature birth. Immunobiology (2012) 217(2):176-86. doi:10.1016/j.imbio.2011.07.027

41. Denny KJ, Woodruff TM, Taylor SM, Callaway LK. Complement in pregnancy: a delicate balance. Am J Reprod Immunol (2013) 69(1):3-11. doi:10.1111/aji. 12000

42. Peng Q, Li K, Sacks SH, Zhou W. The role of anaphylatoxins C3a and C5a in regulating innate and adaptive immune responses. Inflamm Allergy Drug Targets (2009) 8(3):236-46. doi:10.2174/187152809788681038
43. Grumach AS, Ceccon ME, Rutz R, Fertig A, Kirschfink M. Complement profile in neonates of different gestational ages. Scand J Immunol (2014) 79(4):276-81. doi:10.1111/sji.12154

44. Wolach B, Dolfin T, Regev R, Gilboa S, Schlesinger M. The development of the complement system after 28 weeks' gestation. Acta Paediatr (1997) 86(5):523-7. doi:10.1111/j.1651-2227.1997.tb08924.x

45. Wagner MH, Sonntag J, Strauss E, Obladen M. Complement and contact activation related to surfactant response in respiratory distress syndrome. Pediatr Res (1999) 45(1):14-8. doi:10.1203/00006450-199901000-00004

46. Ahmed S, Kemp MW, Payne MS, Kallapur SG, Stock SJ, Marsh HC, et al. Comparison of complement activity in adult and preterm sheep serum. Am J Reprod Immunol (2014). doi:10.1111/aji.12299

47. Ganz T. Defensins: antimicrobial peptides of innate immunity. Nat Rev Immunol (2003) 3(9):710-20. doi:10.1038/nri1180

48. Nam BH, Moon JY, Kim YO, Kong HJ, Kim WJ, Lee SJ, et al. Multiple $\beta$-defensin isoforms identified in early developmental stages of the teleost Paralichthys olivaceus. Fish Shellfish Immunol (2010) 28(2):267-74. doi:10.1016/j.fsi.2009.11. 004

49. Meade KG, Higgs R, Lloyd AT, Giles S, O’Farrelly C. Differential antimicrobial peptide gene expression patterns during early chicken embryological development. Dev Comp Immunol (2009) 33(4):516-24. doi:10.1016/j.dci.2008.10.003

50. Alibardi L. Ultrastructural immunocytochemistry suggests that periderm granules in embryonic chick epidermis contain beta-defensins. Acta Histochem (2014) 116(5):943-8. doi:10.1016/j.acthis.2014.03.007

51. Huttner KM, Brezinski-Caliguri DJ, Mahoney MM, Diamond G. Antimicrobial peptide expression is developmentally regulated in the ovine gastrointestinal tract. J Nutr (1998) 128(2 Suppl):297S-9S.

52. Meyerholz DK, Gallup JM, Grubor BM, Evans RB, Tack BF, McCray PB Jr., et al. Developmental expression and distribution of sheep $\beta$-defensin-2. Dev Comp Immunol (2004) 28(2):171-8. doi:10.1016/S0145-305X(03)00105-8

53. Starner TD, Agerberth B, Gudmundsson GH, McCray PB Jr. Expression and activity of $\beta$-defensins and LL-37 in the developing human lung. J Immunol (2005) 174(3):1608-15. doi:10.4049/jimmunol.174.3.1608

54. Schuster C, Gläser R, Fiala C, Eppel W, Harder J, Schröder JM, et al. Prenatal human skin expresses the antimicrobial peptide RNase 7. Arch Dermatol Res (2013) 305(6):545-9. doi:10.1007/s00403-013-1340-y

55. Gschwandtner M, Zhong S, Tschachler A, Mlitz V, Karner S, Elbe-Bürger A, et al. Fetal human keratinocytes produce large amounts of antimicrobial peptides: involvement of histone-methylation processes. J Invest Dermatol (2014) 134(8):2192-201. doi:10.1038/jid.2014.165

56. Akinbi HT, Narendran V, Pass AK, Markart P, Hoath SB. Host defense proteins in vernix caseosa and amniotic fluid. Am J Obstet Gynecol (2004) 191(6):2090-6. doi:10.1016/j.ajog.2004.05.002

57. Iavazzo C, Tassis K, Gourgiotis D, Boutsikou M, Baka S, Hassiakos D, et al. The role of human beta defensins 2 and 3 in the second trimester amniotic fluid in predicting preterm labor and premature rupture of membranes. Arch Gynecol Obstet (2010) 281(5):793-9. doi:10.1007/s00404-009-1155-4

58. Gomez R, Romero R, Ghezzi F, Bo Hyun Y, Mazor M, Berry SM. The fetal inflammatory response syndrome. Am J Obstet Gynecol (1998) 179(1):194-202. doi:10.1016/S0002-9378(98)70272-8

59. Yoon BH, Romero R, Kim KS, Park JS, Ki SH, Kim B II, et al. A systemic fetal inflammatory response and the development of bronchopulmonary dysplasia. Am J Obstet Gynecol (1999) 181(4):773-9. doi:10.1016/S0002-9378(99) 70299- 1

60. Yoon BH, Romero R, Park JS, Kim M, Oh SY, Kim CJ, et al. The relationship among inflammatory lesions of the umbilical cord (funisitis), umbilical cord plasma interleukin 6 concentration, amniotic fluid infection, and neonatal sepsis. Am J Obstet Gynecol (2000) 183(5):1124-9. doi:10.1067/mob.2000.109035

61. Yoon BH, Kim YA, Romero R, Kim JC, Park KH, Kim MH, et al. Association of oligohydramnios in women with preterm premature rupture of membranes with an inflammatory response in fetal, amniotic, and maternal compartments. Am J Obstet Gynecol (1999) 181(4):784-8. doi:10.1016/S00029378(99)70301-7

62. Pacora P, Chaiworapongsa T, Maymon E, Kim YM, Gomez R, Yoon BH, et al. Funisitis and chorionic vasculitis: the histological counterpart of the fetal inflammatory response syndrome. J Matern Fetal Med (2002) 11(1):18-25. doi:10.1080/jmf.11.1.18.25 
63. Lee SE, Romero R, Jung H, Park CW, Park JS, Yoon BH. The intensity of the fetal inflammatory response in intraamniotic inflammation with and without microbial invasion of the amniotic cavity. Am J Obstet Gynecol (2007) 197(3):.e1-6. doi:10.1016/j.ajog.2007.07.006

64. Andrew Combs C, Gravett M, Garite TJ, Hickok DE, Lapidus J, Porreco R, et al. Amniotic fluid infection, inflammation, and colonization in preterm labor with intact membranes. Am J Obstet Gynecol (2014) 210(2):.e1-15. doi:10.1016/j.ajog.2013.11.032

65. DiGiulio DB, Romero R, Kusanovic JP, Gómez R, Kim CJ, Seok KS, et al. Prevalence and diversity of microbes in the amniotic fluid, the fetal inflammatory response, and pregnancy outcome in women with preterm prelabor rupture of membranes. Am J Reprod Immunol (2010) 64(1):38-57. doi:10.1111/j.1600-0897.2010.00830.x

66. Xiao L, Crabb DM, Dai Y, Chen Y, Waites KB, Prescott Atkinson T. Suppression of antimicrobial peptide expression by Ureaplasma species. Infect Immun (2014) 82(4):1657-65. doi:10.1128/IAI.01231-13

67. Estrada-Gutierrez G, Gomez-Lopez N, Zaga-Clavellina V, Giono-Cerezo S, Espejel-Nuñez A, Gonzalez-Jimenez MA, et al. Interaction between pathogenic bacteria and intrauterine leukocytes triggers alternative molecular signaling cascades leading to labor in women. Infect Immun (2010) 78(11):4792-9. doi:10.1128/IAI.00522-10

68. Manimtim WM, Hasday JD, Hester L, Fairchild KD, Lovchik JC, Viscardi RM. Ureaplasma urealyticum modulates endotoxin-induced cytokine release by human monocytes derived from preterm and term newborns and adults. Infect Immun (2001) 69(6):3906-15. doi:10.1128/IAI.69.6.3906-3915.2001

69. Kallapur SG, Kramer BW, Knox CL, Berry CA, Collins JJP, Kemp MW, et al. Chronic fetal exposure to Ureaplasma parvum suppresses innate immune responses in sheep. J Immunol (2011) 187(5):2688-95. doi:10.4049/jimmunol. 1100779

70. Snyder CC, Wolfe KB, Gisslen T, Knox CL, Kemp MW, Kramer BW, et al. Modulation of lipopolysaccharide-induced chorioamnionitis by Ureaplasma parvum in sheep. Am J Obstet Gynecol (2013) 208(5):.e1-8. doi:10.1016/j.ajog.2013.02. 018

71. Bo Hyun Y, Chong Jai K, Romero R, Jong Kwan J, Kyo Hoon P, Seok Tae $\mathrm{C}$, et al. Experimentally induced intrauterine infection causes fetal brain white matter lesions in rabbits. Am J Obstet Gynecol (1997) 177(4):797-802. doi:10.1016/S0002-9378(97)70271-0

72. Davies JK, Shikes RH, Sze CI, Leslie KK, McDuffie RS Jr, Romero R, et al. Histologic inflammation in the maternal and fetal compartments in a rabbit model of acute intra-amniotic infection. Am J Obstet Gynecol (2000) 183(5):1088-93. doi: $10.1067 / \mathrm{mob} .2000 .108888$

73. Kallapur SG, Willet KE, Jobe AH, Ikegami M, Bachurski CJ. Intra-amniotic endotoxin: chorioamnionitis precedes lung maturation in preterm lambs. $\mathrm{Am}$ J Physiol Lung Cell Mol Physiol (2001) 280(3 24-3):L527-36.

74. Kemp MW, Saito M, Nitsos I, Jobe A, Kallapur S, Newnham J. Exposure to in utero lipopolysaccharide induces inflammation in the fetal ovine skin. Reprod Sci (2011) 18(1):88-9. doi:10.1177/1933719110380470

75. Kramer BW, Kallapur SG, Moss TJ, Nitsos I, Newnham JP, Jobe AH. Intraamniotic LPS modulation of TLR signaling in lung and blood monocytes of fetal sheep. Innate Immun (2009) 15(2):101-7. doi:10.1177/1753425908100455 Epub 2009/03/26.,

76. Kramer BW, Moss TJ, Willet KE, Newnham JP, Sly PD, Kallapur SG, et al. Dose and time response after intraamniotic endotoxin in preterm lambs. Am J Respir Crit Care Med (2001) 164(6):982-8. doi:10.1164/ajrccm.164.6.2103061

77. Nitsos I, Rees SM, Duncan J, Kramer BW, Harding R, Newnham JP, et al. Chronic exposure to intra-amniotic lipopolysaccharide affects the ovine fetal brain. J Soc Gynecol Investig (2006) 13(4):239-47. doi:10.1016/j.jsgi.2006.02. 011

78. Novy MJ, Duffy L, Axthelm MK, Sadowsky DW, Witkin SS, Gravett MG, et al. Ureaplasma parvum or Mycoplasma hominis as sole pathogens cause chorioamnionitis, preterm delivery, and fetal pneumonia in rhesus macaques. Reprod Sci (2009) 16(1):56-70. doi:10.1177/1933719108325508

79. Kemp MW, Saito M, Kallapur S, Jobe A, Keelan JA, Li S, et al. Inflammation of the fetal ovine skin following in utero exposure to Ureaplasma parvum. Reprod Sci (2011) 18(11):1128-37. doi:10.1177/1933719111408114

80. Moss TJM, Knox CL, Kallapur SG, Nitsos I, Theodoropoulos C, Newnham JP, et al. Experimental amniotic fluid infection in sheep: effects of Ureaplasma parvum serovars 3 and 6 on preterm or term fetal sheep. Am J Obstet Gynecol (2008) 198(1):.e1-8. doi:10.1016/j.ajog.2007.06.065
81. Moss TJM, Nitsos I, Ikegami M, Jobe AH, Newnham JP. Experimental intrauterine Ureaplasma infection in sheep. Am J Obstet Gynecol (2005) 192(4):1179-86. doi:10.1016/j.ajog.2004.11.063

82. Kemp MW, Miura Y, Payne MS, Watts R, Megharaj S, Jobe AH, et al. Repeated maternal intramuscular or intraamniotic erythromycin incompletely resolves intrauterine Ureaplasma parvum infection in a sheep model of pregnancy. Am J Obstet Gynecol (2014) 211(2):.e1-9. doi:10.1016/j.ajog.2014.02. 025

83. Goldenberg RL, Andrews WW, Faye-Petersen OM, Goepfert AR, Cliver SP, Hauth JC. The alabama preterm birth study: intrauterine infection and placental histologic findings in preterm births of males and females less than 32 weeks. Am J Obstet Gynecol (2006) 195(6):1533-7. doi:10.1016/j.ajog.2006.05.023

84. Romero R, Lafreniere D, Duff GW, Kadar N, Durum S, Hobbins JC. Failure of endotoxin to cross the chorioamniotic membranes in vitro. Am J Perinatol (1987) 4(4):360-2. doi:10.1055/s-2007-999808

85. Duncan JR, Cock ML, Scheerlinck JPY, Westcott KT, McLean C, Harding $\mathrm{R}$, et al. White matter injury after repeated endotoxin exposure in the preterm ovine fetus. Pediatr Res (2002) 52(6):941-9. doi:10.1203/00006450200212000-00021

86. Duncan JR, Cock ML, Suzuki K, Scheerlinck JPY, Harding R, Rees SM. Chronic endotoxin exposure causes brain injury in the ovine fetus in the absence of hypoxemia. J Soc Gynecol Investig (2006) 13(2):87-96. doi:10.1016/j.jsgi.2005. 12.003

87. Newnham JP, Shub A, Jobe AH, Bird PS, Ikegami M, Nitsos I, et al. The effects of intra-amniotic injection of periodontopathic lipopolysaccharides in sheep. Am J Obstet Gynecol (2005) 193(2):313-21. doi:10.1016/j.ajog.2005.03.065

88. Peltier MR, Drobek CO, Bhat G, Saade G, Fortunato SJ, Menon R. Amniotic fluid and maternal race influence responsiveness of fetal membranes to bacteria. J Reprod Immunol (2012) 96(1-2):68-78. doi:10.1016/j.jri.2012.07.006

89. Lauweryns J, Bernat R, Lerut A, Detournay G. Intrauterine pneumonia. An experimental study. Biol Neonate (1973) 22(3-4):301-18. doi:10.1159/ 000240562

90. Willet KE, Jobe AH, Ikegami M, Newnham J, Brennan S, Sly PD. Antenatal endotoxin and glucocorticoid effects on lung morphometry in preterm lambs. Pediatr Res (2000) 48(6):782-8. doi:10.1203/00006450-200012000-00014

91. Kramer BW, Kramer S, Ikegami M, Jobe AH. Injury, inflammation, and remodeling in fetal sheep lung after intra-amniotic endotoxin. Am J Physiol Lung Cell Mol Physiol (2002) 283(2 27-2):L452-9.

92. Jobe AH, Newnham JP, Willet KE, Moss TJ, Gore Ervin M, Padbury JF, et al. Endotoxin-induced lung maturation in preterm lambs is not mediated by cortisol. Am J Respir Crit Care Med (2000) 162(5):1656-61. doi:10.1164/ajrccm. 162.5.2003044

93. Scott RJ, Peat D, Rhodes CA. Investigation of the fetal pulmonary inflammatory reaction in chorioamnionitis, using an in situ Y chromosome marker. Pediatr Pathol (1994) 14(6):997-1003. doi:10.3109/15513819409037696

94. Kemp MW, Kannan PS, Saito M, Newnham JP, Cox T, Jobe AH, et al. Selective exposure of the fetal lung and skin/amnion (but not gastro-intestinal tract) to LPS elicits acute systemic inflammation in fetal sheep. PLoS One (2013) 8(5):1-9. doi:10.1371/journal.pone.0063355

95. Gisslen T, Hillman NH, Musk GC, Kemp MW, Kramer BW, Senthamaraikannan $P$, et al. Repeated exposure to intra-amniotic LPS partially protects against adverse effects of intravenous LPS in preterm lambs. Innate Immun (2014) 20(2):214-24. doi:10.1177/1753425913488430

96. Wolfs TGAM, Kramer BW, Thuijls G, Kemp MW, Saito M, Willems MGM, et al. Chorioamnionitis-induced fetal gut injury is mediated by direct gut exposure of inflammatory mediators or by lung inflammation. Am J Physiol Gastrointest Liver Physiol (2014) 306(5):G382-93. doi:10.1152/ajpgi.00260.2013

97. Wilson TC, Bachurski CJ, Ikegami M, Jobe AH, Kallapur SG. Pulmonary and systemic induction of SAA3 after ventilation and endotoxin in preterm lambs. Pediatr Res (2005) 58(6):1204-9. doi:10.1203/01.pdr.0000185269. 93228.29

98. Kramer BW, Ikegami M, Moss TJM, Nitsos I, Newnham JP, Jobe AH. Endotoxin-induced chorioamnionitis modulates innate immunity of monocytes in preterm sheep. Am J Respir Crit Care Med (2005) 171(1):73-7. doi:10.1164/rccm.200406-745OC

99. Cheah FC, Pillow JJ, Kramer BW, Polglase GR, Nitsos I, Newnham JP, et al. Airway inflammatory cell responses to intra-amniotic lipopolysaccharide in a sheep model of chorioamnionitis. Am J Physiol Lung Cell Mol Physiol (2009) 296(3):L384-93. doi:10.1152/ajplung.90547.2008 
100. Saito M, Payne MS, Miura Y, Ireland DJ, Stock S, Kallapur SG, et al. Polymyxin B agonist capture therapy for intrauterine inflammation: proofof-principle in a fetal ovine model. Reprod Sci (2014) 21(5):623-31. doi:10. 1177/1933719113508820

101. Vincent MC, Trapnell BC, Baughman RP, Wert SE, Whitsett JA, Iwamoto HS. Adenovirus-mediated gene transfer to the respiratory tract of fetal sheep in utero. Hum Gene Ther (1995) 6(8):1019-28. doi:10.1089/hum.1995.6.81019

102. Iwamoto HS, Trapnell BC, McConnell CJ, Daugherty C, Whitsett JA. Pulmonary inflammation associated with repeated, prenatal exposure to an E1, E3-deleted adenoviral vector in sheep. Gene Ther (1999) 6(1):98-106. doi:10.1038/sj.gt.3300804

103. Rothman BL, Merrow M, Despins A, Kennedy T, Kreutzer DL. Effect of lipopolysaccharide on C3 and C5 production by human lung cells. J Immunol (1989) 143(1):196-202.

104. Newnham JP, Moss TJ, Kramer BW, Nitsos I, Ikegami M, Jobe AH. The fetal maturational and inflammatory responses to different routes of endotoxin infusion in sheep. Am J Obstet Gynecol (2002) 186(5):1062-8. doi:10.1067/ mob.2002.122293

105. Collins JJP, Kallapur SG, Knox CL, Nitsos I, Polglase GR, Pillow JJ, et al. Inflammation in fetal sheep from intra-amniotic injection of Ureaplasma parvum. Am J Physiol Lung Cell Mol Physiol (2010) 299(6):L852-60. doi:10.1152/ajplung. 00183.2010

106. Schmidt AF, Kannan PS, Kemp MW, Kramer BW, Newnham JP, Jobe AH, et al. Intraamniotic LPS modulates expression of antimicrobial peptides in the fetal sheep lung. Pediatr Res (2014) 8(10):113. doi:10.1038/pr.2014.113

107. Sadowsky DW, Adams KM, Gravett MG, Witkin SS, Novy MJ. Preterm labor is induced by intraamniotic infusions of interleukin- $1 \beta$ and tumor necrosis factor- $\alpha$ but not by interleukin- 6 or interleukin- 8 in a nonhuman primate model. Am J Obstet Gynecol (2006) 195(6):1578-89. doi:10.1016/j.ajog.2006. 06.072

108. Kallapur SG, Moss TJM, Auten RL Jr, Nitsos I, Pillow JJ, Kramer BW, et al. IL8 signaling does not mediate intra-amniotic LPS-induced inflammation and maturation in preterm fetal lamb lung. Am J Physiol Lung Cell Mol Physiol (2009) 297(3):L512-9. doi:10.1152/ajplung.00105.2009

109. Ikegami M, Moss TJM, Kallapur SG, Mulrooney N, Kramer BW, Nitsos I, et al. Minimal lung and systemic responses to TNF- $\alpha$ in preterm sheep. Am J Physiol Lung Cell Mol Physiol (2003) 285(1 29-1):L121-9.

110. Willet KE, Kramer BW, Kallapur SG, Ikegami M, Newnham JP, Moss TJ, et al. Intra-amniotic injection of IL-1 induces inflammation and maturation in fetal sheep lung. Am J Physiol Lung Cell Mol Physiol (2002) 282(3 26-3):L411-20.

111. Bry K, Lappalainen U, Hallman M. Intraamniotic interleukin-1 accelerates surfactant protein synthesis in fetal rabbits and improves lung stability after premature birth. J Clin Invest (1997) 99(12):2992-9. doi:10.1172/JCI119494

112. Sosenko IRS, Kallapur SG, Nitsos I, Moss TJM, Newnham JP, Ikegami M, et al. IL- $1 \alpha$ causes lung inflammation and maturation by direct effects on preterm fetal lamb lungs. Pediatr Res (2006) 60(3):294-8. doi:10.1203/01.pdr. 0000233115.51309.d3

113. Underwood MA, Gilbert WM, Sherman MP. Amniotic fluid: not just fetal urine anymore. J Perinatol (2005) 25(5):341-8. doi:10.1038/sj.jp.7211290

114. Shermeta DW, Oesch I. Characteristics of fetal lung fluid production. J Pediatr Surg (1981) 16(6):943-6. doi:10.1016/S0022-3468(81)80850-0

115. Tomoda S, Brace RA, Longo LD. Amniotic fluid volume and fetal swallowing rate in sheep. Am J Physiol (1985) 249(1 Pt 2):R133-8.

116. Wolfs TGAM, Buurman WA, Zoer B, Moonen RMJ, Derikx JPM, Thuijls G, et al. Endotoxin induced chorioamnionitis prevents intestinal development during gestation in fetal sheep. PLoS One (2009) 4(6):1-12. doi:10.1371/journal.pone. 0005837

117. Oh KJ, Lee KA, Sohn YK, Park CW, Hong JS, Romero R, et al. Intraamniotic infection with genital mycoplasmas exhibits a more intense inflammatory response than intraamniotic infection with other microorganisms in patients with preterm premature rupture of membranes. Am J Obstet Gynecol (2010) 203(3):.e1-8. doi:10.1016/j.ajog.2010.03.035

118. Romero R, Kusanovic JP, Gomez R, Lamont R, Bytautiene E, Garfield $\mathrm{RE}$, et al. The clinical significance of eosinophils in the amniotic fluid in preterm labor. J Matern Fetal Neonatal Med (2010) 23(4):320-9. doi:10.3109/ 14767050903168465

119. Sampson JE, Theve RP, Blatman RN, Shipp TD, Blanchi DW, Ward BE, et al. Fetal origin of amniotic fluid polymorphonuclear leukocytes. Am J Obstet Gynecol (1997) 176(1 I):77-81. doi:10.1016/S0002-9378(97)80015-4

120. Grigg JM, Barber A, Silverman M. Increased levels of bronchoalveolar lavage fluid interleukin- 6 in preterm ventilated infants after prolonged rupture of membranes. Am Rev Respir Dis (1992) 145(4 I):782-6. doi:10.1164/ajrccm/ 145.4_Pt_1.782

121. Arai H, Matsuda T, Goto R, Takada G. Increased numbers of macrophages in tracheal aspirates in premature infants with funisitis. Pediatr Int (2008) 50(2):184-8. doi:10.1111/j.1442-200X.2008.02558.x

122. Kim YM, Romero R, Chaiworapongsa T, Espinoza J, Mor G, Kim CJ. Dermatitis as a component of the fetal inflammatory response syndrome is associated with activation of toll-like receptors in epidermal keratinocytes. Histopathology (2006) 49(5):506-14. doi:10.1111/j.1365-2559.2006.02542.x

123. Zhang L, Saito M, Jobe A, Kallapur SG, Newnham JP, Cox T, et al. Intraamniotic administration of E. coli lipopolysaccharides causes sustained inflammation of the fetal skin in sheep. Reprod Sci (2012) 19(11):1181-9. doi:10.1177/ 1933719112446079

124. Schuster C, Vaculik C, Prior M, Fiala C, Mildner M, Eppel W, et al. Phenotypic characterization of leukocytes in prenatal human dermis. J Invest Dermatol (2012) 132(11):2581-92. doi:10.1038/jid.2012.187

125. Dorschner RA, Lin KH, Murakami M, Gallo RL. Neonatal skin in mice and humans expresses increased levels of antimicrobial peptides: innate immunity during development of the adaptive response. Pediatr Res (2003) 53(4):566-72. doi:10.1203/01.PDR.0000057205.64451.B7

126. Marchini G, Lindow S, Brismar H, Ståbi B, Berggren V, Ulfgren AK, et al. The newborn infant is protected by an innate antimicrobial barrier: peptide antibiotics are present in the skin and vernix caseosa. Br J Dermatol (2002) 147(6):1127-34. doi:10.1046/j.1365-2133.2002.05014.x

127. Wolfs TGAM, Kallapur SG, Polglase GR, Pillow JJ, Nitsos I, Newnham JP, et al. IL-1 $\alpha$ mediated chorioamnionitis induces depletion of FoxP3+ cells and ilea inflammation in the ovine fetal gut. PLoS One (2011) 6(3). doi:10.1371/journal. pone. 0018355

128. Kramer BW, Kallapur SG, Moss TJM, Nitsos I, Polglase GP, Newnham JP, et al. Modulation of fetal inflammatory response on exposure to lipopolysaccharide by chorioamnion, lung, or gut in sheep. Am J Obstet Gynecol (2010) 202(1):.e1-9. doi:10.1016/j.ajog.2009.07.058

Conflict of Interest Statement: The author declares that the research was conducted in the absence of any commercial or financial relationships that could be construed as a potential conflict of interest.

Received: 31 August 2014; accepted: 27 October 2014; published online: 01 December 2014.

Citation: Kemp MW (2014) Preterm birth, intrauterine infection, and fetal inflammation. Front. Immunol. 5:574. doi: 10.3389/fimmu.2014.00574

This article was submitted to Inflammation, a section of the journal Frontiers in Immunology.

Copyright (c) 2014 Kemp. This is an open-access article distributed under the terms of the Creative Commons Attribution License (CC BY). The use, distribution or reproduction in other forums is permitted, provided the original author(s) or licensor are credited and that the original publication in this journal is cited, in accordance with accepted academic practice. No use, distribution or reproduction is permitted which does not comply with these terms. 